\title{
Language Problem in African Philosophy: The Igala Case
}

\author{
Egbunu, Fidelis Eleojo (PhD)
}

Department of Philosophy and Religious Studies, Kogi State University, Anyigba, Kogi State, Nigeria Email: frfidele@yahoo.com

\section{Doi:10.5901/jesr.2014.v4n3p363}

\begin{abstract}
The Language Question is a very central subject of discourse in African Philosophy. This is consequent upon the fact that the essence of language in philosophy cannot be gainsaid. Language, as it were, is culture bound. As such, to deny a people of their language is to deny them their cultural heritage. While applying the descriptive and analytic method in this work, it is contended that language plays not only a catalyzing role in the art of philosophizing but that it occupies an inalienable place in philosophy. Again, that since philosophy is more or less about resolving "conceptual cramps" or "bottle-necks", indigenous languages should be given a pride of place over and against their foreign counterparts because of the obvious epistemological advantages embedded therein (especially in mother-tongues). It is submitted here that a lot of homework need to be done in terms of advocacy and development on the low status of such languages so as to meet up with the international standard and nature of the discipline. Meanwhile, the need for using a language that engenders understanding across ethnic barriers alongside the language of the environment is being advocated as a short-term measure. This is not without sounding a caveat that such a transfer of knowledge which is often fraught with some degree of adulteration via the instrument of translation, though practicable, is far from being the ideal. It is on this token the opinions of experts such as Barry Hallen, Quine and a host of others on Methods of Ordinary Language Philosophy and Indeterminacy, respectively are being advanced as plausible means of meeting the challenges before us. In this manner, while using the Igala language of Central Nigeria as a case study, it is finally submitted that it is possible to have what we might term authentic African Philosophy emerging from a systematic analysis of our traditional worldviews.
\end{abstract}

\section{Introduction}

Premised on the fact that philosophy is more about conceptual clarifications and analysis (Okolo 18, Afolayan 41, Oyeshile 134), contemporary African philosophers are confronted with certain linguistic problems. As it is firmly assumed, especially within the analytic tradition that "most philosophical disputes resolve themselves once what Wittgenstein calls "the conceptual cramps" in the language of discourse are removed" (Sogolo 25). In this case, the basic preoccupation of language philosophy is conceptual clarifications, grammatical forms, their functions, and so on. The question arises as to what extent trans-cultural transfer of meanings could take place without distorting the original meaning of ideas expressed in a particular language. The dilemma is embedded within a case whereby the philosopher is expected to live within the African context and thought system while he/she writes with the English, French or Portuguese mindset. In other words, the contention lies in the question of whether it is plausible to undertake authentic African philosophy in a language other than an African language. For instance, Igbo Philosophy (Nwala) was not written in Igbo language; Bantu Philosophy (Tempels) was not in Bantu language; Akan Philosophy (Wiredu) was not done in Akan language, etc. Such philosophies were often written in foreign languages, it is either English, French or Portuguese, as the case may be, which are languages of the colonial masters of the various territories. The immediate corollary to the first question is whether such works done in alien languages could actually qualify as African Philosophy. Furthermore, there is also the question of whether such philosophies in foreign languages could sincerely express African ideas and sentiments which they profess to represent. In the course of the attempt to finding solution to such linguistic problems, some scholars have also discovered that the need to decolonize the African mind is a palpable one. It is argued that language is culturebound and as such African Philosophy ought to really portray its unique identity, feelings and empathy.

Scholars in the ilk of Ngugi Wa Thiongo, Ogunmodede Francis, Oluwole S, Uroh Chris and others have advocated the essence of employing African language in order to authenticate African Philosophy. To this group "a philosophy is a philology" (Unamino in Olabiyi 13).

In this case, the problem of language is considered central, since "it is the vehicle of the philosophers' thought and it plays an important role in the way people know and understand" (Azenabor 41). On the other hand, scholars such as 
Chinua Achebe, Kwasi Wiredu, Oladipo Segun, Njoku Francis, Afolayan Adesina, Azenabor Godwin and a host of others are of the view that though the use of African languages is of obvious necessity, a lot of other factors have to be taken into consideration. There are therefore, apparently two sides of the divide, namely, those who outrightly argue for African Philosophy in African language here and now and those who are on the side of caution, at least for now. We shall now delve into the central issues in this subject matter as we attempt clarifying key concepts such as "Language", "African Philosophy" and "Igala".

\section{Conceptual Clarification}

"Language", according to Macmillan English Dictionary refers to "the method of human communication using spoken or written words" (843). It also connotes "the particular form of words and speech that is used by the people of a country, area, or social group". Such could also be depicted in "signs, symbols, sounds, and other methods of communicating information, feelings, or ideas" (843). This definition indicates that the higher form of communication is thus implied in our context. It is specifically communication between human persons, it is oral or written, and the geographical location of those concerned also matters. The feelings of those involved are also taken into cognizance along with their unique ideas, signs and symbols. Chambers $21^{\text {st }}$ Century Dictionary in defining language emphasizes how "the majority of a particular community will readily understand" and how it is a "formalized system of communication" (764). In this light, Achebe's argument that "no individual, group or team can give a people a language" (in Asiegbu 118) is implicitly given some credence here. Webster's Ninth New Collegiate Dictionary also lays emphasis on how it is a "systematic means of communicating ideas or feelings by the use of conventionalized signs, sounds, gestures or marks" (672-673). Gleaning from the above definitions, it is quite significant, therefore, to note that language, in our context, is a formalized and systematized vehicle of articulating ideas or feelings, in which signs, gestures or sounds that have been agreed upon by a particular society or understood by them owing to their unique experiences are employed or utilized for the sake of conveying some truth. To a certain degree, language is to philosophy what oxygen is to the human body. A strong connection is made between language and one's world, words and things in the universe. From the analytic perspective, the Wittgenstein aphorism that "the limits of one's language are the limits of one's world" (Cited in Okolo 18) is quite in order. It is language that articulates the worldview or thoughts of the culture of a people. This entails their beliefs and practices, their ideas about God, the universe, fellowmen/women, their politics, economy, religion, organizations and so on. Mondin's definition of language encapsulates these principal points when he stated that it is:

that activity with which man, through vocal or written signs puts himself in communication with his own peers (or with some other intelligent being, for instance, God) to express his own sentiments, desires, or knowledge (133).

It is also understood that among the lower animals, there exist some minimal sort of language which helps them to meet their fundamental needs. However, "language is an exquisitely human activity" Mondin (134). Language in its strict sense is one of the essential features which distinguish human beings from other species of beings that exist in the universe (Fasiku 101). It is "a product of a well-engineered biological instinct" and is specifically "a tool in the formation of metaphysical and epistemological ideas, developing social and moral consciousness of a people" (Fasiku101). Any bid to understand a people more deeply logically demands the need for unfolding the nuances of their language. According to Akwanya (9), study of Language in contemporary times could fall under one of the following formats: First, grammar or linguistics - which is about the determinant of the distributional units in language phenomenon and the rule for counting these into larger and more complex units; second, the semantics - which is about the determination of the rules of interpreting linguistic structures, beginning at the word level and ending at the sentence level, or most complex texts; and then the third, pragmatics - which has to do with the determination of the interactive context, the interrelationship between the user and his language, between the language and the cultural environment, and between the persons among whom the language is exchanged as message-bearing actions. This delineation of areas of study would be very significant in our task of matching the experience and environment of particular speakers of a language with the nature of a language in use.

In his profound analysis of languages from the anthropological viewpoint, Mondin (135-136) mentions three principal elements of languages, namely: Descriptive function; Communicative function and Expressive function. The Descriptive function involves scientific language which is gifted with maximum clarity, precision and objectivity. In its Communicative function, the human person is able to communicate with his/her peers. It is in this sense that the human person is seen as: 
an intersubjective being, a being of dialogue, and not a monad, an island, separated from the rest of the world; but he is instead an open being who realizes himself in communication with others (Mondin 136).

It is particularly in this respect that language is portrayed as an instrument of education. Through language, individual minds/lives are either formed or deformed (corrupted). In other words, "it is central to the interactive process" (Bewaji 271). For Heidegger, for instance, the lack of authenticity of individuals is due above all to language, thus:

the majority of men do not judge for themselves, do not decide of their own account, but think, judge, and decide according to what they have heard said by others (cited in Mondin 137).

In this light, language has a lot to do with a people's identity, personality, feeling, ideas, etc. This second function of language shall remain our basic point of focus in this paper. And it is perhaps, in the third, which is the expressive function that the existential function subsists. Besides the fact that language describes objects and communicates our sentiments and ideas, languages also serve to bear testimony to people and ourselves that we exist. That partly explains why language is often spoken of as "a mirror of reality of culture" (Imbo in Njoku 106) or a treasury or bank of culture and philosophy...how they believe...their conception of love, the hereafter, human dignity, and so on (Ki-Zerbo 94). It expresses the people's uniqueness and is "the principal means whereby culture is accumulated, shared and transmitted from one generation to another" (Kirkness in Omachnonu 169). Without language, knowledge hardly exists (Omachonu 165). In this vein, anything which "endangers the existence, worth or value of language is regarded as a threat" (Bewaji 272) to the people's corporate existence. In other words, it identifies and distinguishes. It confers socio-cultural traits, creating mannerisms or imposing gestural constraints" (Bewaji 272). We shall return to this all-important point later because of its centrality to our subject of discourse. Meanwhile, we may briefly turn unto describing what we mean by "African Philosophy".

"African Philosophy" in our context simply refers to the systematic inquiry into the worldview of Africans. This includes those within the geographical confines of the inhabitants of the continent of Africa or those who are Africans in diaspora. In another sense, those who share common historical experiences with and those who belong to same racial groupings with those within this continent along with those who are perhaps expatriates but who have appropriately disposed themselves to making systematic inquiries into African predicaments. Nature has somehow constrained the author to anchor on his own mother tongue (Igala) with which he is to a very large extent conversant with the nuances of its language. Scholars of other linguistic backgrounds are free to make inputs from other various angles.

"Igala" refers to the language, the territory and the people who are located in the eastern flank of the confluence of rivers Niger and Benue in Kogi State of Nigeria (Egbunu 8). Owing to their central positioning, they are somehow considered as a cultural melting pot and are thus rich in their cultural heritage. They belong to the Yoruboid group of languages in the Niger Congo family (Armstrong 13). We may now turn to the core issue in this work.

\section{Implications of the Usage or Non-Usage of African Languages in African Philosophy}

The proponents of African Language for African Philosophy have advocated that African Philosophy would be made more authentic by writing and/or teaching it in African language. According to them, "the language of a people... is the principal feature that marks them off from other people. It is their essence" (Uroh 138). In this light, "linguistic forms have been said to have powerful control over the minds of people" (Azenabor 41). And as a matter of fact, "language has been said to be a good store of people's ideas about their own environment" (Azenabor 41). Therefore, if "one is able to arrive at the structure of reality of a particular people beginning from their language", (Masolo 245) it would be quite rewarding.

From Uroh's point of view, the problem gets more compounded or more complicated at the instance "foreign languages with markedly different worldviews are imposed on a people in place of their own language" (139). This is actually the crux of the matter. The implication is that the people in question are thus "forced to perceive themselves through an alien cultural screen" (Uroh 139). It is argued that the resultant effect is inevitably the distortion of their own image. As Uroh rightly inferred, "such a people will suffer an identity crisis, for they will neither really be like 'themselves' nor exactly like the culture they are imitating" (139). This is what Ogunmodede sarcastically referred to as "inauthentic life" or "cultural alienation" (36). This leaves the people in question perpetually under the colonial yoke or tutelage, psychologically, at least, a situation which is not just akin to but worse than a mother spoon-feeding or even at worse breast-feeding a child come of age. This leaves them in a very ridiculous state. In other words, the avowed independence of such a group of people or nation from colonial overlords would only amount to mere verbiage as they remain perpetually intellectually cornered. A similar idea was also expressed by Wiredu when alluding to such foreign structures, 
characteristics and expressions when he affirms how this might affect the nature of a given philosophical position (34). Not withstanding, Wiredu was not unaware of the fact that languages posses both the qualities of flexibility and adaptability which could easily be used in creating avenues for their communicability. Azenabor noted this matter in his treatment of Language Questions in Philosophy when he opined about how "language is not only the vehicle for the expression of thought but also the framework within which thought is formed" (Azenabor 42). Indeed, thoughts are developed or shaped in relation to moulds of particular languages spoken or written. To put our African experience in a foreign mould in our expressions therefore, would be tantamount to forcing alien expressions on our African feelings, ideas or experiences. The resulting thought pattern would be a caricature of the original.

Come to think of it, the African Philosopher so equipped with his/her African worldviews or thoughts in its beautiful array of signs, symbols, marks, arts, proverbs, legends, folktales, and several other interesting moulds therein attempts to force the foreign language on this wealth of knowledge. The disastrous consequence of such a hotchpotch mentality of portraying the African culture in a foreign garb is to say the least, ridiculous. The resulting mismatch of such abstract or theoretical articulation of what might have been an otherwise practical, palpable and deeply pragmatic experience is better imagined than expressed. In a nutshell, this would be an almost impossible task because culture forms the basis of both language and philosophy. To stand language against culture would therefore be standing it on its head, which can never be sustained in producing an authentic philosophy, be it African philosophy or otherwise.

Ngugi wa Thiongo is even more fierce in this light, when from the socio-political angle he vehemently asserted that, "any attempt at cultural decolonization carried out within the ambit of the European languages is already a capitulation to European cultural standards crudely disguised as "universalism" (xvii). To Ngugi, this is a clear way of shaping the socio-political consciousness of the users of such foreign languages by which means such Africans are exiled from their own languages, their culture and thereby denied their collective self-identity. In advocating the decolonization of the African mind, Ngugi then suggests that "Eurocentrism is most dangerous to the self-confidence of third-world peoples when it becomes internalized in their intellectual conception of the universe" (xviii). This actually led this great African scholar to the extreme of declaring that he would henceforth stop writing in any of the foreign languages.

I believe that my writing in Gikuyu language, a Kenyan language, an African language is part and parcel of the anti-imperialist struggles of Kenyan and African peoples (Ngugi 163).

In fact, earlier on, he had argued:

We as African writers have always complained about the neo-colonial economic and political relationship to EuroAmerica. Right. But by our continuing to write in foreign languages, paying homage to them, are we not on the cultural level continuing that neocolonial slavish and cringing spirit? What is the difference between a politician who says Africa cannot do without imperialism and the writer who says Africa cannot do without European languages? (Ngugi 162).

Kwasi Wiredu on the other hand, saw the need for the use of the indigenous language in doing Authentic African Philosophy. However, he was more realistic in considering that it involves a great deal of bottlenecks before ever a wellmeaning philosopher could take a reasonable dive. He therefore sounds a caveat, thereby, cautioning that good intentions are not enough. To him, if not "until unity is achieved in Africa to make it possible to realize the idea of a continental lingua franca" (Wiredu 35), such an enterprise would not be so practicable. And so he sums it up by affirming that any attempt:

to counterbalance this possibility, the African philosopher will have to practice thinking things out in his language as well as in the foreign ones, a program that is easier prescribed than implemented, but to which there is no alternative (Wiredu 20).

This, he believes would be achievable by "being always on the look out for any conceptual snares" (Wiredu 21). He thus outlines certain concepts for critical reflection:

Reality, Being, Existence, Thing, Object, Entity, Substance, Property, Quality, Truth, Fact, Opinion, Belief, Knowledge, Faith, Doubt, Certainty, Statement, Proposition, Sentence, Idea, Mind, Soul, Spirit, Thought, Sensation, Matter, Ego, Self, Person, Individuality, Community, Subjectivity, Objectivity, Cause, Chance, Reason, Explanation, Meaning, Freedom, Responsibility, Punishment, Democracy, Justice, God, World, Universe, Nature, Supernature, Space, Time, Nothingness, Creation, Life, Death, Afterlife, Morality, Religion (Wiredu 23).

In the course of trying to think out possible words or thoughts that could compare with such terms as are 
mentioned above, the writer personally discovered how tasking it is. And this is because at many levels, the indigenous languages are yet to achieve some reasonable level of development or what Omachonu (64) refers to as "language empowerment". This according to him would:

enable it cope with the new function(s). Language empowerment in this instance is a language development strategy, which involves serious language planning, management and maintenance. Corpus planning refers to changes in language structure: vocabulary, syntax, morphology, orthography or even the adoption of a new script (Omachonu 64).

He also expatiates on the other arm of language planning which relates to a language's standing vis-à-vis other languages (Ndukwe 133). By and large, the entire enterprise would entail other arms of the planning such as dictionary compilation, spelling reform, writing of school texts, literature/literary texts, terminology/meta-language development, language revival, translation, etc. (Emenanjo, Anagbogu and Bamgbose in Omachonu 64-65).

As a matter of fact, it is very apparent in the Nigerian environment, for instance, that many of the linguistic groups are far behind in the light of meeting up with the standard of development that is required for better implementation of some of the salient ideas espoused above. The Igbo linguistic group in Nigeria, for example, has been crying over Language endangerment. And one could observe in that regard through the annual Ihejioku, Odenigbo and presently via Suwakwa (Nonyelum 95, Asiegbu 114, Ewuzie 44). The Igala linguistic group is not any better in this regard. Therefore, the recent efforts of certain scholars such as Omachonu, Miachi, Atadoga, Idegu, and others along with the Igala Education Summit in this light are expected to pay off in due course towards enhancing indigenous knowledge (see Omachonu 38, Idegu 2). And even though the Yoruba and Hausa linguistic groups in Nigeria seem to be faring better in the development and usage of their languages at a relatively understandable level at the international level, the dispute has always arisen as to what African language is worthy enough as a Pan-African language. Swahili, had been suggested at some stage in African history but this was greeted with a lot of controversies. This leaves us almost at square one when the idea of using the indigenous languages in doing African philosophy is being espoused.

Such scholars are also not unaware of the low status of the local languages. The bone of contention therefore, is perhaps, that since philosophy is an international discipline, resorting to indigenous languages inadvertently narrows down one's scope to so limited an audience. The foreign languages (English, French or Portuguese) which are lingua franca and ostensibly the language of business, intellectual activity and/or prestige carries with them immediate advantages which are not readily palpable through the indigenous languages. Omachonu lends his voice to this truth when he made a point on "Negative language attitude" (62) which is manifest among the people in many ways. He went further to emphasize how "foreign languages are more favourably or positively regarded in Nigeria than the indigenous ones" (62) since the foreign languages are associated with prestige. It is even argued among scholars who belong to the other school of thought that within this singular idea of promoting our indigenous languages lie the danger of ethnocentricism within our own very ranks. It is as a result of this also that Bewaji holds that if learning a language brings one closer to the culture that the language codifies, it is also necessary to recognize that imposing a continental language (Pan-Africanistically desirable as that may be) may only amount to the imposition of a culture (alien) on others (278). Soyinka's FESTAC 1977 suggestion of a continental language is therefore suspect. To him, that is "an ideal whose realisability is at best dubious" (Bewaji 278). This sort of skepticism is obviously informed by stark lack of confidence in the ability of fellow Africans to rise to some level of agreement and/or development. Nevertheless, it must be stated that the journey of a thousand miles begins with a single step. As it is often said, "non-ventured non-gained". It may be understood then that any agreement on an African language as a lingua franca would by every standard be more preferable, taking into cognizance the fact that our common African heritage in the historical experiences, shared ideas and sentiments are closer to themselves than the foreign categories with an altogether different background. There is surely every "need for a language that cuts across ethnic barriers" (Ibrahim 87) and such is possible even from the wide gamut of at least 400 linguistic groups in Africa.

Behind this pessimistic attitude at the academic level, there exists an undercurrent of the attitude of our educated men/women. They are "not only merely proud of their mastery of English, they also celebrate their ignorance of their mother tongue" (Omachonu 63). As Ngugi succinctly describes this sort of attitude: "He measures his modernity by the distance he has been able to establish between himself and his mother tongue" (cited in Omachonu 63). With such a mindset, such parents are not only ashamed of speaking in the indigenous language to their children, much less, teach them. Omachonu captured this trend when he stated "it is as if the languages to them are leprous and should be avoided" (63). And putting it differently, Idegu observed that, "it is almost becoming a taboo for Igala parents to speak their language with their children even at home" (9).

It is even most appalling when one realizes that The National Policy on Education (12) recommends the teaching 
of language of the immediate environment for the first three years. This point is better understood if it is viewed from the perspective of "restoration of African personality" (Enoh 268). The case for the use of mother tongue in education is not so much that of Africans having been miseducated, although this constitutes part of the critique of the imposed language. Fafunwa advanced the view that the imposition of an alien language of instruction is "one of the important factors that militate against the dissemination of knowledge and skills and therefore of rapid social and economic wellbeing of the majority of people in developing countries" (vii). He further emphasizes that "language that one has never been happy in, never been angry in, never made love in, a language that is only for school, is no language in which to develop the enterprise of the mind" (Fafunwa 101). By this crucial points the renowned professor and veteran federal Minister of Education in the second Republic argued that the Nigerian medium of instruction in our educational system was fraught more than anything else with the epistemological problem. It is instructive that the European Trade Union Committee for Education (ETUCE) calls on every European citizen to learn how to speak, read and write his/her native language. The declaration is of the view that "languages are a crucial part of every culture. This underlines the right of every child to learn his or her mother-tongue, the language of the society" (1). The intellectual development of children in several dimensions such as originality, initiative, manual dexterity, spontaneity and so forth are made possible through the mother tongue which is the most natural way to learn. As it were, mother tongues are especially the key to creativity and productivity.

No disputing the truth that most of the African languages are yet to be fully developed even at the level of orthography, syntax and vocabularies. The Ihejioku, Odenigbo and Suwakwa of the Igbos and the Igala Studies Association (IGSA) of Igala land and others are welcome developments in the right direction.

Azenabor's opinion that "indigenous languages are hardly accorded high status in many of our African countries" (43) is true to the fact. Actually, what we observe especially in Nigeria, is some sparse presence of native language studies in some higher institutions. For the Igala, it is basically at the Kogi State College of Education that there exists an Igala Unit under the development of language arts. Igala language study is yet to see the light of day in the State University.

Considering the various forms of bottle-necks involved in the task of developing indigenous languages to the level of general acceptability whereby they would be employed appropriately in doing authentic African philosophy, we are rightly cautioned. The way of prudence seems surely the best step in this respect. If we were to keep waiting till such a time when we would have a general lingua franca we may not begin at all. And since the continental lingua franca is not yet in sight, the most reasonable efforts would have to begin at the different corners of the various linguistic groups. However, since African languages are local and of low status, while the discipline of philosophy itself is an international one in nature, the level-headed thing then would be to engage in translation of concepts into either English, French or Portuguese. This would enable the philosopher to reach out to the target audience in sharing whatever philosophical experiences are available. This may not be the ideal, but it is perhaps the most plausible thing to do for now. That not withstanding, it should be borne in mind that in the course of translation from one language to the other there would inevitably arise some ontological fallacies since languages do not share the same logic. This would therefore result into problem of lack of correctness in the translation. Without going into much detail on language analysis, we shall briefly present principal figures in this field and their basic ideologies.

Barry Hallen argues that "the systematic analysis of how concepts are used in ordinary language is an essential methodology of analytic philosophy" (104). In this case, deriving a philosophy from African languages commences with practical understanding of such languages so as to translate carefully the necessary concepts by giving their meanings in the ordinary languages. In his work on Indeterminacy and Universality of Meaning, Hallen opines that the process of translation is fraught with distortions owing to bias. For example, as a result of imposing English meanings upon other languages in the process of translation, there is bound to be bias. He attributes this bias to the fact that "each natural language is a unique human creation that has its own intricate conceptual network(s), ontologically, epistemologically, aesthetically, etc with distinctive semantic dispositions".

Quine's Indeterminacy Thesis (IT) went beyond the linguistic realm to the ontological. He raises doubts about ability of the translator to wade through "conceptual networks" embedded within the alien language. Because of the nuances or layers of meanings involved, the task is not to be taken for granted. The translation must not depend on the words alone because of symbolic representations in the language e.g. in the behaviours or gestures. He talks of the need for Hermeneutics and Radical Translation (RT) which must put into consideration the behaviouristic universe (Hallen 390). He also mentions Ontological Relativity (OR) whereby through one's sense organ, he/she gets the necessary information. It is understood here that different languages possess different means of carrying out the dissection of reality. He holds that linguists are doomed to fail in this exercise without the knowledge of the entire linguistic system of 
the native's culture.

Quine's thesis dwells on the principle of Indeterminacy of Translation. In this theory, he harped on certain dimensions of a discourse, that it would be impossible to render meaning of any particular assertion exactly the way it is if it is translated from one language to the other. This is especially so on issues pertaining to the belief systems or worldviews and societal values all of which are culture dependent (Sogolo 28). In other words, the meanings attached to particular concepts or statements in one language are defined by the totality of the culture in question (Sogolo 28). Quine is not in any way denying outrightly the possibility of translating from one cultural background to the other. The point at issue here is that the translator easily faces the risk of imposing his/her own language perspectives on the foreign one. In Sogolo's view, what Quine means is that, "in translating our language into an alien one or an alien language into ours, we must not pretend that the original meanings are conveyed" (Sogolo 28). The contention therefore is that with the absence of our own mother tongue through which we could analyze and clearly decipher via our own natural African cultural experience, all that we would barely achieve would be mere adulteration of the original meaning of what is being translated.

Whorf Benjamin in his Linguistic Relativity $(L R)$ is of the view that there ought to be a "metaphysical space" for language and its use in a particular community. That is, our experience of the world is defined by language and our personhood is affected by our language. It "shapes our distinctive ways of being in the world... is the carrier of a people's identity, the vehicle of a certain way of seeing things, experiencing and feeling, determinant of particular outlooks on life" (158-159).

In this case, he desires to show that "ordinary languages are loaded with worldviews and metaphysics and more significantly, a person's language determines, at least, in part, the way he perceives and conceives the world" (Oladipo 44). That is why Akwanya would advocate that there is need of "taking possession of elements which pertain to the ream of what is left unsaid, hidden in the people's mind" (194) in the movement from one language to another in language learning. From all indications, it is the particular language community in which we grew up that influences to a very large extent whatever we become.

By and large, one thing is certain about language transfers. Omachonu noted this point when he observed that in "language transfer, two things happen. Either language is deformed or the psyche is deformed" (165). Furthermore, he threw more light, thus: "a transfer or translation, if even it is done by the best of translators, can never be as original or undiluted as the indigenous" (169). Aside the difficulty of readily finding terms or words which are equivalent in the two languages that could adequately encapsulate the idea or feelings expressed, there also exist the issue of use of symbols, signs, or artistic imageries to depict certain abstractions.

\section{The Igala Case}

Among the Igala people, for instance, the speaker may not necessarily need to complete a statement. While speaking to an audience, once a reference is made to a particular animal, the meaning of the proverb or wise-saying is conveyed in a particular context. A few examples might suffice:

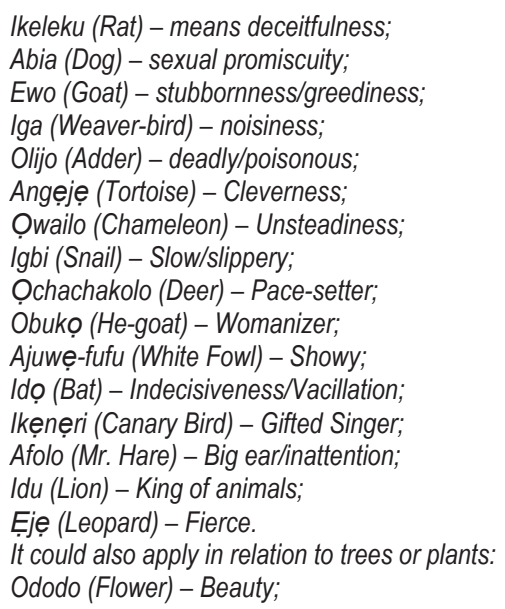




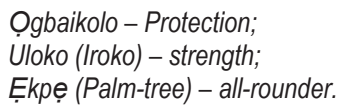

We ought to note at this juncture too that it is not in all cases that the meaning of such words are conveyed in exactly the same manner as when it was directly translated. In most cases, the luster, flavor or meaning of such proverbs or wise-sayings are lost in the course of making such interpretations or translations. When an Igala says, "me bi uchu me bi ọka" (literal translation is "give birth to yams and millet"). Meanwhile, what is intended is a blessing - "may you go and multiply in giving birth to both male and female children"; "Anẹ ki hiebutu, ki hiọkpakpalan" (literally means let the land bring up dust and not hardness) which really means "wishing you bumper harvest" or "prosperity"; "Oli ki gwome wa ki gwome dabi alo" (literally, let the trees that hit you on your way here hit you as you return) meaning "may God grant you safety"; "Ogijo ch'eta iche" (an elder is a pit) meaning "an elder bears many burdens. i.e. uneasy lies the head that wears the crown".

From the few examples given, it is very glaring that it is almost impossible to convey the exact meaning of those translations into English. As it were, if transliterated, it would sound meaningless. Owing to the people's worldviews, informed by their beliefs and cultural values, what we arrive at in the event of any translation for now are what we might refer to as adulterated versions which reduces and hides the actual meanings. This is because every comparison is odious, even in the indigenous languages. This becomes even worse in relation to foreign categories such as those mentioned by Wiredu earlier in this work (Being, Causality, Reality, Religion, etc.). But mere mastery of the word might not be enough (Afolayan 48).

Considering the fall-outs involved in the translation of various concepts, we may need to reiterate that even if translation is not the ideal thing, since the ideal is not practicable in our present African environment, it is pertinent to make do with what is practicable until such a time when there emerges more plausible alternatives.

Meanwhile, it might be suggested that certain manuals be agreed upon at the different levels with set yardsticks or standards, even if there may not exist "direct experience of universal meanings" (Hallen 379). However, an objective Cross-cultural evaluative criteria could, for instance, be found in the biological unity of humankind e.g. in such constitutive activities as "building, farming, child-bearing, love-making, hunting, buying and selling, eating, etc" "translation bridgeheads" which is not language-dependent could be found. This is also possible with "cultural universals" e.g. social organizations, burial customs, child-bearing, kinship relations, forms of social punishment and restitution, etc. There are also cultural particulars (see Afoloyan 48).

\section{Conclusion}

From the foregoing, we have seen that it is safer for an African writer or philosopher to think and feel in his own very language and then look for an English transliteration approximating the original (Afoloyan 55). This may not be very ideal but it is alright and practicable enough, at least, in the present dispensation.

Language should not be made the sole determinant of what we would consider as authentic African philosophy. For now, it is perhaps proper to continue doing African philosophy in whichever languages are tenable universally, whether such languages (such as English, French or Portuguese) are alien is not what actually matters in this context. The crucial issue is whether they serve to make our African thoughts intelligible and comprehensible enough at the universal level. As Azenabor rightly and graphically defended,

In the experience of African people... language does not determine the authenticity of African Philosophy. Authentic African philosophy is that philosophy that is applied to the conceptual problems of African life and experience (47).

\section{References}

Achebe, C. Morning Yet on Creation Day. Heinemann: London, 1975.

Afolayan, A. "The Language Question in African Philosophy" in Oladipo, O. (Ed.) Core Issues in African Philosophy. Hope Publications: Ibadan, 2006.

Akwanya, A.N. Language and Habits of Thought. New Generation Books: Enugu, 1999.

Armstrong, R.G. The Study of West African Languages. IUP: Ibadan, 1967.

Asiegbu, M.F. "Igbo Language Under Threat: A Study in Endangered Languages" in Maryland Studies - An International Journal of Philosophy and African Studies, Vol. 3, June 2006, Pp. 107-127.

Azenabor, G. Understanding the Problems on African Philosophy. First Academic Publishers: Lagos, 1998. 
Bewaji, J.A.I. "African Languages and Critical Discourse" in Oladibo, O. (ed.) The Third Way in African Philosophy. Hope Publications: Ibadan, 2002.

Chambers 21st Century Dictionary. Chambers: India, 1999.

Egbunu, F.E. Igala Traditional Values Versus Modernity. Afro-Orbis: Nsukka, 2009.

Enoh, A.D. Main Currents in Nigerian Educational Thought. Midland Press: Jos, 1996.

Ewuzie, A. "Dying Nigerian Language" in Daily Sun, July 25, 2012, Pp. 43-44.

Ezeani, E. Education in Nigeria - Problems, Dilemmas and Perspectives. Veritas Lumen: London, 2005.

Fafunwa, B. Macaulay, J.I. and Sokoya, F. Education in Mother Tongue: The Ife Primary Education Project. University Press: Ibadan, 1989.

Fasiku, G. "African Philosophy and the Method of Ordinary Language Philosophy" in The Journal of Pan-African Studies, Vol. 2, no 3 , March 2008, Pp. 100-116.

Hallen, B. "Indeterminacy, Ethnophilosophy, Linguistic Philosophy, African Philosophy" in Philosophy: Journal of the Royal Institute of Philosophy, Vol. 70, No. 273, July 1995, p.372.

Hallen, B. "Modes of Thought, Ordinary Language and Cognitive Diversity," in Sumner and Yohannes (eds.) Perspectives in African Philosophy: An Anthology on "Problematics of an African Philosophy: Twenty Years After (1976-1996)". Addis Ababa University Press: Addis Ababa, 2002. p.215.

Ibrahim, J.O. "Language as a Vehicle for Cultural and Democratic Renaissance" in Menegbe, A.D. and Omachonu, G.S. Cultural Renaissance and National Development in the 21st Century. Roots Books and Journals: Abuja, 2008. Pp. 84-91.

Idegu, E.U. "A Language and a People with the Obvious Threat of Extinction: Igala Language Education as a Paradigm" Being a Paper Presented at the 2012 Igala Education Summit, KSU, Anyigba.

Imbo, S.O. An Introduction to African Philosophy. Rowan and Littlefield: Maryland, 1998.

Ki-Zerbo, J. (ed.) General History of Africa, Vol. 1: Methodology and African Prehistory. University of California Press: Berkely, 1990.

Macmillan English Dictionary for Advanced Learners. Macmilla: Oxford, 2007.

Makinde, M.A. African Philosophy: The Demise of a Controversy. OAU Press: Ile-Ife, 2007.

Masolo, D.A. African Philosophy in Search of Identity. Indiana University Press: Bloomington, 1994.

Mondin, B. Philosophical Anthropology. Theological Publications: Bangalore, 2007.

Ngugi, W. Moving the Center. The Struggle for Cultural Freedoms. Heinemann: Portsmouth, 1993.

Ngugi, W. "The Language of African Literature" in Post-Colonialism an Anthology of Cultural Theory and Criticism. Berge: Oxford, 2005, Pp. 143-168.

Njoku, F.O.C. Essays in African Philosophy, Thought Theology. Claretian: Owerri, 2002.

Nonyelim, O. "Language Endangerment: The Case of Igbo" in Ogirisi - A New Journal of African Studies, Vol. 2, No. 1, Pp. 92-100, June 2004.

Nwala, T.U. Igbo Philosophy. Literamed: Lagos, 1985.

Ogunmodede, F. "Of History and Historiography in African Philosophy" cited in Azenabor,

G. Understanding the Problem on African Philosophy. First Academic Publishers: Lagos, 1998.

Okolo, C.B. African Philosophy: A Short Introduction. CECTA: Enugu, 1993.

Olabiyi, T. "Theory and Practice in African Philosophy" in Second Order, Vol. VI, No.2, July 1977, p.13.

Oladipo, O. Core Issues in African Philosophy. Hope Publications: Ibadan, 2006.

Oluwole, S.B. "The Africanness of Philosophy" in Readings in African Philosophy. Masslech Publishers: Lagos, 1989, p.226.

Omachonu, G.S. "Language Attitude as the Bane of Cultural Renaissance and National Development in Nigeria: Speaking Frankly to Ourselves" in Menegbe, A.D. and Omachonu, G.S. Cultural Renaissance and National Development in the 21st Century. Roots Books and Journals: Abuja, 2008. Pp.59-66.

Omachonu, G.S. "Indigenous Languages in the Development of Indigenous Knowledge" in NJIKAD - Nigerian Journal of Indigenous Knowledge and Development, Vol. 1, March 2009, Pp.165-174.

Onyeshile, O.A. "What has Philosophy got to do with Language?" in WAJOPS - West African Journal of Philosophical Studies, Vol. 11, December 2005, Pp. 129-145.

Quine, W.V.O. Word and Object. MIT Press: Massachusetts, 1960.

Sogolo, G. Foundations of African Philosophy - A Definitive Analysis of Conceptual Issues in African Thought. Ibadan University Press: Ibadan, 1993.

Tempels, P. Bantu Philosophy. Presence Africaine: Paris, 1959.

The National Policy on Education. FRN: Lagos, 2005.

Uroh, C. "Colonialism and the Language Question". A Reply to Godfrey Tangwa in Quest Philosophical Discussions, Vol. VIII, No. 2, December, 1994, p.138.

Webster's Ninth New Collegiate Dictionary. Merrian Webster: Spring Field, 1990.

Whorf, B.L. cited in Daniel, B. Communitarianism and its Critics. Clarendon Press: Oxford, 1993.

Wiredu, K. Conceptual Decolonization in African Philosophies - Essays. Hope Publications: Ibadan, 1995. 
